\author{
Антонюк П.О. \\ кандидат економічних наук, науковий співробітник \\ відділ ринкових механізмів і структур \\ Інститут проблем ринку та економіко-екологічних \\ досліджень НАН України \\ Французький бульвар, 29, м. Одеса, Україна, 65044 \\ E-mail: paul_antonyuk@ukr.net \\ ORCID ID: 0000-0002-8100-2563 \\ Ступницька Т.M. \\ кандидат економічних наук, доцент \\ кафедра обліку та аудиту \\ E-mail: t.stupnitska@gmail.com \\ ORCID ID: 0000-0002-2517-2795
}

\author{
Антонюк О.П. \\ кандидат економічних наук, доцент \\ кафедра обліку та аудиту \\ E-mail: olegantoni@ukr.net \\ ORCID ID: 0000-0002-9182-4982
}

\section{Баранюк X.O. \\ асистент}

кафедра обліку та аудиту

Одеська національна академія харчових технологій вул. Канатна, 112, м. Одеса, Україна, 65039

E-mail: baranyuk.kristina@gmail.com ORCID ID: 0000-0002-3346-0332

\title{
СТАТИСТИЧНА ОЦІНКА ФОРМУВАННЯ ЗОВНІШНЬОЇ ТОРГІВЛІ УКРАЇНИ ГОТОВИМИ ХАРЧОВИМИ ПРОДУКТАМИ
}

В статті розглянуто сучасний стан зовнішньої торгівлі готовими харчовими продуктами на основі методів і прийомів статистичного аналізу. В основу дослідження покладено поділ готових харчових продуктів на дві групи в залежності від характеру їх кінцевого споживання. Досліджено товарну та географічну структури експорту та імпорту готових харчових продуктів з точки зору значення товарів названих двох груп в зовнішньоторговельному обороті. Проведено порівняльний аналіз обсягів експорту та імпорту в розрізі продуктів харчування - товарні групи 16-22, та товарні групи 23-24, що не являються такими. Зроблено висновки, що в експорті готових харчових продуктів переважають товари, що не є продуктами харчування людей. Натомість в імпорті переважають саме продукти харчування людей, що свідчить про наявність певних проблем в забезпеченні внутрішнього ринку цими товарами. Встановлено характер впливу цих двох типів товарних груп на фрормування торговельного сальдо, та основі причини перевищення вартості імпорту над експортом. У висновках представлено рекомендації стосовно можливостей зростання експорту готових харчових продуктів та зменшення від'ємного сальдо.

Ключові слова: агропродовольча продукція, готові харчові продукти, продукти харчування людей, експорт, імпорт, сальдо, товарна структура, географічна структура, статистична оцінка.

This work is licensed under a Creative Commons Attribution 4.0 International License http://creativecommons.org/licenses/by/4.0/

Постановка проблеми та її зв'язок з важливими науковими та практичними завданнями. Експорт агропромислової продукції відіграє важливу роль у реалізації експортного потенціалу держави, забезпеченні валютних надходжень, підтримки зовнішньоторговельного балансу. Останніми роками в структурі експорту агропродовольчої продукції зменшується частка товарів 3 високою доданою вартістю, насамперед, готових харчових продуктів, натомість в імпорті їх частка збільшується, формуючи зростаюче від'ємне сальдо. В середньому за рік в 2015-2019 рр. експорт готових харчових продуктів зростав на 106,9 $\%$, а імпорт на $-112,9 \%$. За цей період частка готових харчових продуктів в загальному експорті агропромислової продукції склала 15,8 \%, а в імпорті - 45,5 \%. В цей період серед товарів по чотирьох розділах продукції УКТЗЕД лише по товарах четвертого роз- ділу, готові харчові продукти, існує від'ємне сальдо. Орієнтація в задоволенні потреб внутрішнього ринку шляхом нарощування імпорту несе певні загрози продовольчій безпеці держави і прояви негативних явищ в сфері виробництва. Необхідність оцінки сучасного стану та тенденцій в зовнішній торгівлі готовими харчовими продуктами, виявлення існуючих диспропорції та опрацювання заходів для зниження їх негативного впливу, визначили актуальність дослідження.

Аналіз останніх публікацій по проблемі. Дослідження стану та тенденцій в зовнішній торгівлі агропромисловою продукцією України висвітлені в роботах багатьох науковців: І.Г. Кириленко [3], Ю.О. Лупенко [7], І.М. Пугачов [4], М.П. Сичевський [5], М.А. Штакал [8] та інші. Проте особливості функціонування ринку готових харчових продуктів та дина- 
мічність зовнішніх умов вимагають постійного аналізу макроекономічних показників цього сегменту зовнішньої торгівлі агропродовольчими товарами.

Формулювання цілей дослідження. Метою даного дослідження $є$ визначення за допомогою статистичного аналізу сучасних рис експортно-імпортної діяльності в розрізі товарної та географічних структур та обгрунтування заходів для поліпшення результатів в зовнішній торгівлі.

Виклад основних результатів та їх обгрунтування. За останні сім років в товарній структурі українського експорту відбулися істотні зрушення починаючи 32014 р. агропродовольча продукція стає головним експортним товаром держави [1]. 3 часом ситуація в цьому плані ще більше змінилася - в 2019 p. в товарному експорті держави частка агропродовольчої продукції досягла 44,2 \%. Зростання значення агропродовольчої продукції відбувається при загальному скороченні товарного експорту з 62306 млн. дол. в 2013 р. до 50055 млн. дол. в 2019 р., або на 19,7 \% і зростанню експорту агропродовольчої продукції за цей період з 16930 млн. дол. до 22143 млн. дол., або на $130,8 \%$.

В товарній структурі агропродовольчого експорту переважають різні види сільськогосподарської продукції і в першу чергу товари другого розділу УКТЗЕД «Продукти рослинного походження», частка яких зросла у 52,3 \% в 2013 р. до 58,3 \% в 2019 р. Натомість поступово скорочується частка товарів четвертого розділу УКТЗЕД «Готові харчові продукти» (\%): 2013 р. - 20,7; 2015 р. - 16,9; 2017 р. - 15,9; 2019 p. - 14,5, що свідчить про зростання сировинної складової в агропродовольчому експорті і зменшенні продукції з високою доданою вартістю. Ці результати є значно нижчими у порівнянні з деякими країнами світовими лідерами експорту агропродовольчої продукції [9].

Готові харчові продукти включають в свій склад продукцію дев'яти товарних груп 16 - 24, що мають відмінності в характері кінцевого споживання. При дослідженні ринку готових харчових продуктів, на наш погляд, доцільно виділити продукти харчування людей - товарні групи 16-22 та 23-24, що не являються такими.

Експорт готових харчових продуктів впродовж 2013-2019 рр. впав настільки, що зростання в наступні три роки не дозволило досягнути початкового рівня (табл. 1).

Динаміка та структура експорту готових харчових продуктів за 2013-2019 рр.

Таблиця 1

(за кодами 16-24 УКТЗЕД)*

\begin{tabular}{|c|c|c|c|c|c|c|c|c|c|}
\hline \multirow{3}{*}{$\begin{array}{c}\text { Код і назва товару по то- } \\
\text { варних групах }\end{array}$} & \multicolumn{8}{|c|}{ Роки } & \multirow{3}{*}{$\begin{array}{c}2019 \text { р. в } \\
\text { \% до } \\
2013 \text { p. }\end{array}$} \\
\hline & \multicolumn{2}{|c|}{2013} & \multicolumn{2}{|c|}{2015} & \multicolumn{2}{|c|}{2017} & \multicolumn{2}{|c|}{2019} & \\
\hline & $\begin{array}{l}\text { млн. } \\
\text { дол. }\end{array}$ & $\%$ & $\begin{array}{l}\text { млн. } \\
\text { дол. }\end{array}$ & $\%$ & $\begin{array}{l}\text { млн. } \\
\text { дол. }\end{array}$ & $\%$ & $\begin{array}{l}\text { млн. } \\
\text { дол. }\end{array}$ & $\%$ & \\
\hline $\begin{array}{l}\text { IV. Готові харчові продук- } \\
\text { ти }\end{array}$ & 3501 & 100,0 & 2468 & 100,0 & 2827 & 100,0 & 3220 & 100,0 & 92,0 \\
\hline $\begin{array}{l}\text { 16. Продукти з м'яса і ри- } \\
\text { би }\end{array}$ & 43 & 1,2 & 12 & 0,5 & 16 & 0,6 & 23 & 0,7 & 53,5 \\
\hline $\begin{array}{l}\text { 17. Цукор та кондитерські } \\
\text { вироби з цукру }\end{array}$ & 259 & 7,4 & 169 & 6,8 & 417 & 14,7 & 254 & 7,9 & 98,1 \\
\hline $\begin{array}{l}\text { 18. Какао та продукти } 3 \\
\text { нього }\end{array}$ & 555 & 15,9 & 187 & 7,6 & 184 & 6,5 & 205 & 6,4 & 36,9 \\
\hline $\begin{array}{l}\text { 19. Готові продукти із зер- } \\
\text { на }\end{array}$ & 412 & 11,8 & 268 & 10,9 & 296 & 10,5 & 269 & 8,3 & 65,3 \\
\hline $\begin{array}{l}\text { 20. Продукти переробки } \\
\text { овочів }\end{array}$ & 404 & 11,5 & 184 & 7,5 & 177 & 6,2 & 192 & 6,0 & 47,5 \\
\hline 21. Різні харчові продукти & 251 & 7,2 & 117 & 4,7 & 121 & 4,3 & 143 & 4,4 & 57,0 \\
\hline $\begin{array}{l}\text { 22. Алкогольні та безалко- } \\
\text { гольні напої, оцет }\end{array}$ & 362 & 10,3 & 184 & 7,4 & 209 & 7,4 & 211 & 6,6 & 58,3 \\
\hline $\begin{array}{l}\text { Всього продуктів харчу- } \\
\text { вання }\end{array}$ & 2286 & 65,3 & 1121 & 45,4 & 1420 & 50,2 & 1296 & 40,3 & 56,7 \\
\hline $\begin{array}{l}\text { 23. Залишки і відходи хар- } \\
\text { чової промисловості }\end{array}$ & 922 & 26,3 & 996 & 40,4 & 1051 & 37,2 & 1486 & 46,1 & 161,2 \\
\hline $\begin{array}{l}\text { 24. Тютюн і промислові } \\
\text { замінники тютюну }\end{array}$ & 293 & 8,4 & 351 & 14,2 & 356 & 12,6 & 438 & 13,6 & 149,5 \\
\hline
\end{tabular}

* Розраховано авторами за даними Державної служби статистики України [2]

3 табл. 1 видно, що в складі готових харчових продуктів скоротився експорт продуктів харчування на 989 млн. дол. або на 43,3 \%. Натомість по товарних групах 23 - 24 експорт за 2013-2019 pp. зріс на 709 млн. дол. тобто на 58,3 \%. Різнонаправлений характер динаміки цих товарних груп істотно змінив структуру експорту готових харчових продуктів. Якщо в 2013 р. головним товаром в складі готових харчових продуктів були продукти харчування людини, то згодом більша частина експорту приходиться на 
залишки і відходи харчової промисловості та тютюн і промислові замінники тютюну: 53,8 \% в 2018 р. і 59,7 $\%$ в 2019 p.

На експорт готових харчових продуктів значною мірою вплинуло скорочення виробництва, а відтак і експорту продуктів харчування та падіння за цей період експортних цін на агропромислову продукцію. В 2019 р. у порівнянні з 2013 р. зменшилось виробництво видів продукції, значна частина яких експортувалася (в \%): соки томатні, яблучні та суміш соків фруктових та овочевих - 34,9; печиво солодке без покриття шоколадом - 32,8; цукерки шоколадні 48,4 ; вироби кондитерські з цукру - 41,4; соуси і продукти для приготування соусів - 15,5; вироби макаронні - 26,2; дріжджі пекарські - 13,1; пиво солодове - 33,7; горілка - 57,4. В результаті цього експорт продуктів харчування у ваговому вимірі скоротився 3 1860 тис. т. до 1393 тис. т., або на 25,1 \%. Одночасно зменшувалися експортні ціни практично на всі види продуктів харчування, а в середньому по товарних групах 16 - 22, ціна за 1 т. зменшилась 31229 дол. до 931 дол., або на 24,3\%.

Розрахунки показали, що зменшення експортної виручки від реалізації продуктів харчування в рівній мірі $є$ результатом, як скорочення фізичного обсягу продаж, так і зменшення цін.

Впродовж 2013-2019 рр. високими темпами зростає експорт продукції, що не $\epsilon$ продуктами харчування людини - товарні групи $23-24$, саме за рахунок яких в останні три роки забезпечується позитивна динаміка експорту готових харчових продуктів.
По продукції цих товарних груп збільшення експорту мало місце виключно за рахунок фізичного обсягу продаж. По товарній групі 23 «Залишки і відходи харчової промисловості» експорт склав 6814 тис. т. в 2019 р. проти 3545 тис. т. в 2013 р., тобто темп зростання склав 192,2 \%, а по товарній групі 24 «Тютюн і промислові замінники тютюну», експорт склав в 2019 p. 44,4 тис. т. проти 24,7 тис. т. в 2013 р., що свідчить про темп зростання - 179,8 \%. Такі високі темпи зростання в значній мірі зменшили негативний вплив на вартість експорту зниження експортних цін по продукції товарної групи 23 на 19,2 \%, а товарної групи 24 - на $16,9 \%$.

Характерною рисою зовнішньої торгівлі України $є$ низький ступінь товарної диверсифікації експортних потоків агропродовольчої продукції, в т.ч. і готових харчових продуктів. Із 55 найменувань товарних позицій експорту за чотиризначними кодами з товарних груп 16-24 УКТЗЕД на вісім позицій приходиться 72,9 \% валютної виручки. Незначною в товарній структурі експорту готових харчових продуктів залишається частка ковбас та аналогічних виробів 3 м'яса $(0,05 \%)$, овочів консервованих $(0,17 \%)$, варення та джемів $(0,13 \%)$, виноградних вин $(0,34$ $\%)$, спирту етилового $(0,14 \%)$, продуктів, що використовуються для годівлі тварин $(0,67 \%)$ тощо.

Загальний обсяг експорту, а також товарна структура в значній мірі визначається географією експортних потоків готових харчових продуктів, що представлено в табл. 2.

Таблиця 2

Географічна структура експорту готових харчових продуктів за 2013 та 2019 рр.*

\begin{tabular}{|c|c|c|c|c|c|c|c|}
\hline \multirow{3}{*}{\multicolumn{2}{|c|}{ Напрями експорту }} & \multicolumn{3}{|c|}{2013 p. } & \multicolumn{3}{|c|}{2019 p. } \\
\hline & & \multirow{2}{*}{$\begin{array}{c}\text { Всього гото- } \\
\text { вих харчових } \\
\text { продуктів }\end{array}$} & \multicolumn{2}{|c|}{ в т.ч. товарні групи } & \multirow{2}{*}{$\begin{array}{c}\text { Всього го- } \\
\text { тових хар- } \\
\text { чових про- } \\
\text { дуктів }\end{array}$} & \multicolumn{2}{|c|}{ в т.ч. товарні групи } \\
\hline & & & & & & & \\
\hline \multirow{2}{*}{ СНД } & млн. дол. & 2203 & 1829 & 374 & 805 & 483 & 322 \\
\hline & В $\%$ & 62,9 & 80,0 & 30,8 & 25,0 & 37,3 & 16,7 \\
\hline \multirow{2}{*}{$\mathrm{EC}$} & млн. дол. & 769 & 279 & 490 & 942 & 412 & 530 \\
\hline & В $\%$ & 22,0 & 12,2 & 40,3 & 29,3 & 31,8 & 27,6 \\
\hline \multirow{2}{*}{ Країни Азї̈ } & млн. дол. & 434 & 162 & 272 & 1103 & 220 & 883 \\
\hline & В $\%$ & 12,4 & 7,1 & 22,4 & 34,2 & 17,0 & 45,9 \\
\hline \multirow{2}{*}{$\begin{array}{c}\text { Інші країни } \\
\text { Світу }\end{array}$} & млн. дол. & 95 & 16 & 79 & 370 & 181 & 189 \\
\hline & в $\%$ & 2,7 & 0,7 & 6,5 & 11,5 & 13,9 & 9,8 \\
\hline \multirow{2}{*}{ Разом } & млн. дол. & 3501 & 2286 & 1215 & 3220 & 1296 & 1924 \\
\hline & В $\%$ & 100,0 & 100,0 & 100,0 & 100,0 & 100,0 & 100,0 \\
\hline
\end{tabular}

* Розраховано авторами за даними Державної служби статистики України [2]

Аналізуючи географічну структуру ( табл.2) слід зазначити, що за цей період напрями товарних потоків суттєво змінилися. Країни СНД, що були основними імпортерами готових харчових продуктів 3 України, особливо продукції товарних груп 16-22, значно скоротили обсяги закупівель і останніми роками більша частина вітчизняного експорту направляється в країни Азії та Європейського Союзу. Звер- тає на себе увагу особливість структури експортних потоків готової продукції по різних напрямах світового ринку. Якщо в експорті до країн СНД переважають продукти харчування людини, то інші регіони світу імпортують в більшій мірі продукцію товарних груп 23-24 і головним чином залишки та відходи харчової промисловості. Вітчизняні виробники продукціï товарних груп 16-22 до цього часу 
виявилися неспроможними вийти на зовнішні ринки 3 якісними високотехнологічними, конкурентними продуктами харчування. Якщо в країнах СНД імпортери задовольняються існуючими показниками якості i помірною ціною, то такий принцип не працює на інших ринках i, особливо, країн Свропейського Союзу, де надзвичайно високі вимоги до якості продукції.

Зменшення експорту продуктів харчування в країни СНД на 1346 млн. дол. лише частково - на 356 млн. дол. було перекрито збільшенням поставок в інші регіони світового ринку і скоротило в підсумку експорт на 990 млн. дол., що внесло істотні зміни в товарну та географічну структури. Якщо в 2013 р. серед десятки найбільших імпортерів готових харчових продуктів було п'ять держав - членів СНД з часткою 56,2 \%, то в 2019 р. їх залишилось лише три з часткою 17,8 \% від загальної суми експорту з України. Російська Федерація втратила свої позиції найбільшого імпортера готових харчових продуктів 3 України. Серед країн ЄС значний експорт готових харчових продуктів прямує до Польщі і Франції, в деякі роки до Нідерландів, в Азії постійними партнерами являються Грузія та Туреччина, а в останні два роки і Китай (табл. 3).

Таблиця 3

ТОП-10 найбільших імпортерів готових харчових продуктів з України*

\begin{tabular}{|c|c|c|c|c|c|c|c|c|}
\hline \multirow[b]{2}{*}{$\begin{array}{l}\text { № } \\
\Pi / \Pi\end{array}$} & \multicolumn{2}{|c|}{2013 p. } & \multirow[b]{2}{*}{$\begin{array}{l}\text { № } \\
\Pi / \Pi\end{array}$} & \multicolumn{2}{|c|}{$2017 \mathrm{p}}$. & \multirow[b]{2}{*}{$\begin{array}{c}\text { № } \\
\Pi / \Pi\end{array}$} & \multicolumn{2}{|c|}{$2019 \mathrm{p}}$. \\
\hline & Країна & $\begin{array}{c}\text { \% у екс- } \\
\text { порті }\end{array}$ & & Країна & $\begin{array}{c}\text { \% у } \\
\text { екс- } \\
\text { порті }\end{array}$ & & Країна & $\begin{array}{l}\% \text { у } \\
\text { екс- } \\
\text { порті }\end{array}$ \\
\hline 1 & $\begin{array}{l}\text { Російська Феде- } \\
\text { рація }\end{array}$ & 31,7 & 1 & Білорусь & 9,5 & 1 & Білорусь & 9,5 \\
\hline 2 & Білорусь & 9,6 & 2 & Туреччина & 7,2 & 2 & Китай & 9,0 \\
\hline 3 & Польща & 7,6 & 3 & Польща & 6,1 & 3 & Польща & 7,9 \\
\hline 4 & Молдова & 5,6 & 4 & Грузія & 5,9 & 4 & Туреччина & 7,8 \\
\hline 5 & Грузія & 5,0 & 5 & Молдова & 5,1 & 5 & Грузія & 5,1 \\
\hline 6 & Казахстан & 4,9 & 6 & Франція & 4,1 & 6 & Молдова & 4,5 \\
\hline 7 & Азербайджан & 4,4 & 7 & Азербайджан & 3,8 & 7 & Азербайджан & 3,8 \\
\hline 8 & Франція & 3,6 & 8 & Казахстан & 3,6 & 8 & Франція & 3,2 \\
\hline 9 & Туреччина & 3,6 & 9 & Іспанія & 2,9 & 9 & Єгипет & 2,7 \\
\hline 10 & Ізраїль & 2,0 & 10 & Єгипет & 2,6 & 10 & Нідерланди & 2,4 \\
\hline
\end{tabular}

* Розраховано авторами за даними Державної служби статистики України [2]

3 даних табл. 3 видно, що для більшості країн 3 цього переліку основним імпортним товаром $є$ залишки і відходи харчової промисловості, на які прийшлось в 2019 р. від загального імпорту готових харчових продуктів (\%): Білорусь - 55,4; Китай - 94,5; Туреччина - 91,2; Польща - 64,4; Нідерланди - 81,2; Франція - 97,7. Для Франції залишки і відходи харчової промисловості займають другу позицію після насіння і плодів олійних рослин у всьому товарному імпорті з України [11]. Китай, який тривалий час не проявляв зацікавленості в вітчизняній продукції, стає найбільшим імпортером макухи соняшникової: в 2018 р. - 619 тис. т., в 2019 р.- 1269 тис. т. або 14,4\% і 26,6 \%, відповідно, українського експорту. Крім того, Польща, Грузія, а також країни СНД являються найбільшими і стабільними імпортерами продуктів харчування в розрізі окремих товарних груп.

Продукти 3 м'яса і риби в значних обсягах імпортують Грузія та Республіка Молдова. За 20182019 рр. в ці країни з України було експортовано продукції на суму 18,8 млн. дол., або 42,2 \% усього експорту. Цукор та кондитерські вироби з цукру головним чином направляються в Азербайджан, Білорусь, Молдову, а також - Казахстан, Таджикистан, Узбекистан. За останні два роки в цьому напряму відправлено продукції на суму 273,5 млн. дол., або 44,0 \% цієї товарної групи. Серед країн ЄС значні обсяги імпорту прийшлися на Литву, Німеччину, Польщу,
Румунію - 70,7 млн. дол., або 11,3 \%.

3 товарної групи «Какао та продукти з нього» експортуються в основному продукти товарної позиції 1806 - шоколад та інші готові харчові продукти 3 вмістом какао. При скороченні обсягу експорту цієї продукції з 164,8 тис. т. в 2013 р. до 63,9 тис. т. в 2019 р. основні імпортери не змінилися - це Грузія і країни СНД - Азербайджан, Білорусь, Казахстан, Молдова, Російська Федерація. В 2017-2019 рр. в ці країни було відправлено 47,0 \% всього експорту продуктів переробки какао.

В експорті готових продуктів із зерна найбільші поставки ідуть до країн СНД - Азербайджан, Білорусь, Казахстан та Молдова, країн СС - Румунія, Німеччина, а із країн Азії - до Грузії. Впродовж 20182019 рр. ці сім країн імпортували продукції із зерна на суму 292 млн. дол., або 54,4 \% вітчизняного експорту.

Як у виробництві, так і в експорті продуктів переробки овочів відбувається значний спад, який змінив напрями експортних потоків продукції. Якщо в 2013 р. 58,5 \% продукції експортувалися до країн СНД, то в останні три роки найбільше продукції імпортують країни $\mathrm{CC}-46,4$ \% із них 44,4 \% приходиться на Польщу, Австрію, Німеччину. 3 країн СНД найбільше продукції імпортує Білорусь - 12,2 \% вітчизняного експорту. Нарощують імпорт продукції США - в 2019 р. до 35,3 млн. дол., або 18,4\%. 
Один $з$ найменших обсягів експорту спостерігається по різних харчових продуктах. Як і по інших товарних групах тут змінилися і обсяги, і напрями експортних потоків. В 2013 р. в країни СНД було поставлено 81,4 \% різних харчових продуктів. В 2019 p. цей експорт з України до країн СС та СНД майже зрівнявся - 56,3 млн. дол. і 56,6 млн. дол., відповідно. Найбільшими імпортерами в два останні роки були Молдова, Білорусь, Латвія, Російська Федерація, Німеччина, Польща, а також Грузія.

Експорт алкогольних та безалкогольних напоїв, оцту скоротився за період 2013-2019 рр. на 151 млн. дол., або на 41,7 \% головним чином по причині зменшення імпорту країнами СНД. Проте на сьогодні найбільшими країнами імпортерами напоїв залишилися саме країни СНД - Білорусь, Молдова, Казахстан. Серед країн СС напоїв найбільше закуповує Польща, а серед країн Азії - Грузія та Ізраїль.
Аналіз свідчить про те, що основними державами - імпортерами продуктів харчування людини 3 України залишаються країни СНД. 3 країн Азії найбільшим імпортером залишається Грузія. Свропейський ринок досить насичений продуктами харчування та захищений цілою системою обмежень залишається в певній мірі недоступним для вітчизняних експортерів. Серед країн СС - 28, лише Австрія, Латвія, Литва, Німеччина та Румунія імпортують продукти харчування з України в значних обсягах, але лише по одній - двом товарним позиціям.

Для забезпечення виробництва окремих видів продукції, їх експорту, на потреби внутрішнього ринку здійснюється імпорт різних видів агропродовольчої продукції, в тому числі і готових харчових продуктів. Їх значення в зовнішній торгівлі держави визначається обсягами експорту і імпорту, та іншими похідними показниками (табл. 4).

Таблиця 4

Показники експорту та імпорту готових харчових продуктів за 2015-2019 рр.*

\begin{tabular}{|c|c|c|c|c|c|c|}
\hline \multirow[b]{2}{*}{ Показники } & \multicolumn{5}{|c|}{ Роки } & \multirow{2}{*}{$\begin{array}{c}2019 \text { р. в \% за } \\
2015 \text { р. }\end{array}$} \\
\hline & 2015 & 2016 & 2017 & 2018 & 2019 & \\
\hline $\begin{array}{l}\text { 1. Експорт, млн. дол. } \\
\text { в т.ч. товарні групи }\end{array}$ & 2468 & 2450 & 2827 & 3019 & 3220 & 130,5 \\
\hline $16-22$ & 1121 & 1145 & 1420 & 1396 & 1296 & 115,6 \\
\hline $23-24$ & 1347 & 1305 & 1407 & 1623 & 1924 & 142,8 \\
\hline $\begin{array}{l}\text { 2. Імпорт, млн. дол. } \\
\text { в т.ч. товарні групи }\end{array}$ & 1608 & 1734 & 1935 & 2341 & 2616 & 162,7 \\
\hline $16-22$ & 1044 & 1152 & 1363 & 1704 & 1888 & 180,8 \\
\hline $23-24$ & 564 & 582 & 572 & 637 & 728 & 129,1 \\
\hline $\begin{array}{l}\text { 3. Зовнішньо торговельний оборот, } \\
\text { млн. дол. }\end{array}$ & 4076 & 4184 & 4762 & 5360 & 5837 & 143,2 \\
\hline 4. Сальдо, млн. дол. & 860 & 716 & 892 & 678 & 604 & 70,2 \\
\hline $\begin{array}{l}\text { 5. Частка готових харчових продук- } \\
\text { тів в агропродовольчій продукції, \% } \\
\text { - в експорті } \\
\text { - в імпорті } \\
\text { - в сальдо }\end{array}$ & $\begin{array}{c}16,9 \\
46,2 \\
7,8\end{array}$ & $\begin{array}{c}16,0 \\
44,6 \\
6,3\end{array}$ & $\begin{array}{c}15,9 \\
45,0 \\
6,6\end{array}$ & $\begin{array}{c}16,2 \\
46,3 \\
5,0\end{array}$ & $\begin{array}{c}14,5 \\
45,6 \\
3,7\end{array}$ & $\begin{array}{l}x \\
x \\
x\end{array}$ \\
\hline $\begin{array}{l}\text { 6. Коефіцієнт покриття імпорту екс- } \\
\text { портом }\end{array}$ & 1,53 & 1,41 & 1,46 & 1,29 & 1,23 & 80,4 \\
\hline
\end{tabular}

* Розраховано авторами за даними Державної служби статистики України [2]

Впродовж останніх п’яти років зростає як експорт готових харчових продуктів так і імпорт, при цьому темпи зростання імпорту значно перевищують темпи збільшення експорту, що призводить до зменшення сальдо і коефіцієнту покриття імпорту експортом. Звертає на себе увагу місце і динаміка готових харчових продуктів в експорті та імпорті агропродовольчих товарів. Якщо в агропродовольчому експорті частка готових харчових продуктів знаходиться в межах 14,5 - 16,9\%, то в імпорті частка зростає до 46,3 \%. В значній мірі це являється результатом відмінності в темпах зростання експорту та імпорту продуктів харчування людини та товарних груп 23 24. В 2015 - 2019 р.р. експорт продуктів харчування зростає на 115,6 \%, в імпорті $-180,8$ \%. По продуктах товарних груп 23 - 24 ситуація протилежна - експорт зростає швидше - 142,8 \% ніж імпорт - 129,1\%.

Найбільший імпорт готових харчових продуктів до України надходить 3 країн Європейського Союзу - в 2017 - 2019 р.p. частка ЄС знаходиться в межах 60 - 64 \%. Україна не в повній мірі використовує зону вільної торгівлі з Свропейським Союзом, що вступила в дію з початку 2016 р. Так, якщо експорт готових харчових продуктів до ЄС за 2017 - 2019 р.p. зріс з 865 млн. дол. до 943 млн. дол., або на 108,9\%, то імпорт збільшився з 1162 млн. дол. до 1682 млн. дол., або на 144,8 \%. ТОП - 5 найбільших імпортерів складають: Італія, Нідерланди, Німеччина, Польща, Франція, на які в 2019 р. прийшлося 68,9 \% імпорту 3 ЄC. Варто зауважити, що не тільки країни $\mathrm{CC} \epsilon$ 
значними імпортерами для України, але й Україна для Європейського Союзу є важливим напрямом їх експорту. В 2019 р. до України з СС було експортовано агропродовольчої продукції (де більша частина це готові харчові продукти) на суму 2455 млн. дол., або 1,4 \% всього їх експорту поза межами Свропейського Союзу [10].
Від'ємні сальдо формується лише при торгівлі продуктами харчування по всіх регіонах i об'єднаннях, крім СНД. В торгівлі товарами товарних груп 23-24 незалежно від регіону отримується додатне сальдо. Слід відзначити специфіку експортно імпортних потоків до країн СС та Азії (табл. 5).

\section{Географія експорту та імпорту готових харчових продуктів в 2019 р.*}

Таблиця 5

(млн. дол.)

\begin{tabular}{|c|c|c|c|c|c|c|c|c|c|}
\hline \multirow{3}{*}{ Регіони } & \multirow{2}{*}{\multicolumn{3}{|c|}{$\begin{array}{c}\text { Всього готових харчових } \\
\text { продуктів }\end{array}$}} & \multicolumn{6}{|c|}{ В тому числі } \\
\hline & & & & \multicolumn{3}{|c|}{ Товарні групи 16 - 22} & \multicolumn{3}{|c|}{ Товарні групи 23 - 24} \\
\hline & $\begin{array}{l}\text { Екс- } \\
\text { порт }\end{array}$ & Імпорт & Сальдо & $\begin{array}{l}\text { Екс- } \\
\text { порт }\end{array}$ & Імпорт & Сальдо & Експорт & Імпорт & Сальдо \\
\hline СНД & 805 & 81 & 724 & 483 & 65 & 418 & 322 & 16 & 306 \\
\hline $\mathrm{EC}$ & 943 & 1682 & -739 & 413 & 1215 & -802 & 530 & 467 & 63 \\
\hline $\begin{array}{l}\text { Країни } \\
\text { Азії }\end{array}$ & 1103 & 363 & 740 & 220 & 294 & -74 & 883 & 69 & 814 \\
\hline Інші & 369 & 490 & -121 & 180 & 314 & -134 & 189 & 176 & 13 \\
\hline Всього & 3220 & 2616 & 604 & 1296 & 1888 & -592 & 1924 & 728 & 1196 \\
\hline
\end{tabular}

*Розраховано авторами за даними Державної служби статистики України [2]

Країни Азії - найбільший імпортер готових харчових продуктів з України і 80,1 \% цього імпорту складають товари товарних групи 23-24, що забезпечує в цілому додатне сальдо. Країни СС - найбільший експортер готових харчових продуктів в Україну i більшу частину експорту - 72,2 \% складають продук- ти харчування людини, по яким завжди формується від'ємне сальдо, що визначає такий результат і в цілому в торгівлі.

Формування сальдо в торгівлі готовими харчовими продуктами, його розмір та динаміка в розрізі товарних груп 16-24 розглядається по даним табл. 6.

Таблиця 6

Динаміка сальдо в торгівлі готовими харчовими продуктами за 2013-2019 рр.*

\begin{tabular}{|c|c|c|c|c|c|c|c|}
\hline \multirow{2}{*}{$\begin{array}{c}\text { Код і назва товару та товарних } \\
\text { групах }\end{array}$} & \multicolumn{7}{|c|}{ Роки, млн. дол. } \\
\hline & 2013 & 2014 & 2015 & 2016 & 2017 & 2018 & 2019 \\
\hline IV. Готові харчові продукти & 322 & 494 & 860 & 716 & 892 & 678 & 604 \\
\hline 16. Продукти з м’яса і риби & -108 & -72 & -30 & -47 & -67 & -71 & -105 \\
\hline $\begin{array}{l}\text { 17. Цукор та кондитерські вироби з цук- } \\
\text { ру }\end{array}$ & 171 & 88 & 135 & 296 & 370 & 300 & 184 \\
\hline 18. Какао та продукти з нього & 94 & -36 & -6 & -55 & -53 & -103 & -122 \\
\hline 19. Готові продукти із зерна & 197 & 221 & 182 & 124 & 179 & 110 & 68 \\
\hline 20. Продукти переробки овочів & 108 & 65 & 70 & 29 & 34 & -9 & 2 \\
\hline 21. Різні харчові продукти & -403 & -318 & -223 & -228 & -243 & -276 & -297 \\
\hline $\begin{array}{l}\text { 22. Алкогольні та безалкогольні напої, } \\
\text { оцет }\end{array}$ & -211 & -171 & -50 & -126 & -164 & -260 & -322 \\
\hline Всього продуктів харчування & -152 & -223 & 78 & -7 & 56 & -309 & -592 \\
\hline $\begin{array}{l}\text { 23. Залишки і відходи харчової промис- } \\
\text { ловості }\end{array}$ & 635 & 866 & 837 & 831 & 885 & 1009 & 1255 \\
\hline $\begin{array}{l}24 . \text { Тютюн і промислові замінники тю- } \\
\text { тюну }\end{array}$ & -161 & -149 & -55 & -108 & -49 & -22 & -59 \\
\hline
\end{tabular}

*Розраховано авторами за даними Державної служби статистики України [2]

Як свідчать дані табл. 6 в 2013-2019 рр. в одних товарних групах формується позитивне сальдо, а в інших від'ємне. В експортно-імпортних операціях 3 продуктами харчування, як правило, від'ємне сальдо, так як додатне сальдо по товарних групах 17, 19, 20 виявляється недостатнім, щоб покрити негативний результат по товарних групах $16,18,21,22$, який в останні п’ять років постійно зростає. Це, особливо, не реально в умовах скорочення експорту та зростання імпорту. Так, по товарах товарної позиції 2204 «Вина виноградні..» в період 2015-2019 рр. експорт скоротився $з$ 38,1 млн. дол. до 11,9 млн. дол., імпорт зріс 3 56,4 млн. дол. до 146,7 млн. дол., а від'ємне сальдо в 2019 році складає 134,8 млн. дол. Франція, один 
3 головних експортерів виноградних вин до України, збільшила свої поставки за ці роки у два рази і успішно продовжує і в поточному році [12].

Найбільше додатне сальдо отримується від залишків та відходів харчової промисловості. В дійсності розмір сальдо дещо більший, проте зменшується за рахунок від'ємного сальдо по товарах товарної позиції 2309 «Продукти, що використовуються для годівлі тварин». Недостатній рівень вітчизняного виробництва, як і в інших товарних позиціях і товарних групах, не в змозі задовольнити потреби внутрішнього ринку та експорту. За період 2013-2019 рр. з України було експортовано продукції для годівлі тварин на суму 117 млн. дол., натомість імпортовано на 1331,3 млн. дол., а від'ємне сальдо склало 1214,3 млн. дол. Сума надзвичайна, враховуючи специфіку кінцевого споживання продукції.

Досягнення позитивного сальдо в торгівлі продуктами харчування, як це мало місце в 2015-2017 pp., або зменшення від'ємного сальдо рівня 2018 2019 рр., слід пов'язувати із зменшенням імпорту продукції товарних позицій в товарних групах 16, 18, 21, 22 і 23, а головним чином, зі збільшенням експорту продукції. Саме завдяки зростанню експорту цукру (тис. т.): 2014 р. - 6,2; 2015 р.- 114,8; 2016 р.- 464,8; 2017 р.- 599,3; 2018 р. - 584,8; 2019 р.- 236,8 по товарах товарної групи 17 «Цукор та кондитерські вироби 3 цукру» досягнуто значного зростання і експортної виручки і додатного сальдо.

Значні можливості для зростання експорту пов'язуються 3 приватизацією спиртових заводів, продукція яких - спирт ректифікований, спирт етиловий технічний, біоетанол користується попитом на світовому ринку. Очікується значне розширення географії експортних потоків спиртопродукції - країни ЄС (Австрія, Польща, Угорщина, Словаччина), Азії (Грузія, Туреччина), СНД (Азербайджан, Туркменістан ) та інші [6].

Від'ємне сальдо в торгівлі товарами в значній мірі $є$ результатом імпорту різноманітних високотехнологічних продуктів харчування по значно вищим цінам в порівнянні з цінами на експортовані товари. За таких умов навіть зростання фізичного обсягу експорту недостатнє для компенсації різниці в цінах. В 2019 році з України по товарній групі 21 «Різні харчові продукти» по шести товарних позиціях було експортовано 107643 т. продуктів на суму 142,7 млн. дол. при середній ціні 1326 дол/т., натомість імпортовано 76051 т. на суму 439,7 млн. дол. по ціні 5782 дол/т., що і сформувало від'ємне сальдо в розмірі 297 млн. дол. В цьому році перевищення імпортних цін над експортними по товарних групах склало (в \%): 16 - 19,2; 17 - 225,3; 18 - 132,4; 19 - 113,7; 20 - 165,5; 21 - 436,4; 22 - 340,8; 23 - 554,6. Перевищення імпортних цін над експортними для готових харчових продуктів ситуація звичайна, крім товарів товарної групи 24 «Тютюн і промислові замінники тютюну», де ситуація з цінами зворотна, а від'ємне сальдо визначається перевищенням фізичного обсягу імпорту над експортом.

Таким чином, результати експортно-імпортних операцій визначаються дією різноманітних факторів, які мають свій специфічний вплив в різних то- варних групах. Проте в основі всіх факторів знаходиться рівень вітчизняного виробництва і можливості вітчизняних експортерів запропонувати іноземним партнерам різноманітні високотехнологічні і конкурентоздатні види харчової продукції.

Висновки та перспективи подальших досліджень. Нестабільність внутрішніх соціальноекономічних процесів внесли суттєві зміни в товарну структуру експорту. Головним експортним товаром в Україні стає агропродовольча продукція, в складі якої скорочується частка готових харчових продуктів продукції з високою доданою вартістю. В складі готових харчових продуктів в процесі аналізу в залежності від характеру кінцевого споживання виділяються власне продукти харчування людей - товарні групи 16-22, та продукція товарних груп 23-24, куди відносяться залишки та відходи харчової промисловості, і тютюн та промислові замінники тютюну.

Різнонаправлений характер динаміки цих товарних груп істотно змінив структуру експорту готових харчових продуктів - більшу частину з 2015 р. складає продукція товарних груп 23-24. Зміни в товарній структурі внесли суттєві корективи в географію експортних поставок. Країни СНД втратили позиції головного імпортера готових харчових продуктів, поступившись країнам Азії та СС. Проте країни СНД попри значне скорочення залишаються найбільшим покупцем продуктів харчування, а друга позиція, як і раніше залишилась за країнами Європейського Союзу, які наростили обсяги імпорту. Найбільші експортні потоки продукції товарних груп 23 - 24 спрямовуються до країн Азії.

Імпорт готових харчових продуктів зростає набагато швидше експорту в результаті чого знижуються такі показники ефективності зовнішньої торгівлі як сальдо і коефіцієнт покриття імпорту експортом. Детальний аналіз формування сальдо показує, що в торгівлі готовими харчовими продуктами отримується стабільне додатне сальдо, хоча інша частина в загальному сальдо в торгівлі агорпродовольчими товарами незначна і продовжує зменшуватися. В торгівлі продуктами харчування результатом є від'ємне сальдо, що формується по товарах товарних груп 16, $18,21,22$. Найбільше позитивне сальдо дає торгівля залишками і відходами харчової промисловості, на які і в експорті приходиться найбільша сума виручки. Головною причиною від'ємного сальдо в торгівлі продуктами харчування $\epsilon$ більш високий рівень цін на імпортовані товари в порівнянні 3 експортованими, що відображає їхню якість, високу технологічність та конкурентоздатність. Виконана оцінка стану та результатів зовнішньої торгівлі готовими харчовими продуктами свідчить про можливість їх зростання.

По-перше, збільшення поставок продуктів харчування до країн СНД, так як це єдиний напрямок, де ця торгівля дає додатне сальдо. По друге, освоєння виробництва та експорт якісних, конкурентоздатних продуктів харчування, що може дати зростання експорту і зменшення імпорту. По-третє, збільшення поставок на ринок країн ЄС товарів товарних груп 17, 19, 20 , які і зараз користуються значним попитом в ряді країн, що зменшить загальне від'ємне сальдо. Почетверте, по можливості обмежити імпорт деяких то- 
варів і в першу чергу товарної позиції 2309 «Продукти, що використовуються для годівлі тварин».

В подальшому дослідження можуть бути направлені на оцінку динаміки та структури експорту товарів інших розділів УКТЗЕД.

\section{Література}

1. Антонюк П.О., Антонюк О.П., Ступницька Т.М., Головаченко Л.М. Стан та результати торгівлі агропродовольчими товарами між Україною і Європейським союзом // Економіка харчової промисловості. 2019. Т.11, вип.1. С. 27-36; doi: 10.15673/fie.v11i1.1292

2. Державна служба статистики України : [Веб - сайт]. Київ, 2021. URL: http://ukrstat.gov.ua/ (дата звернення 10.01.2021).

3. Кириленко І.Г., Івченко В.С., Деменчук В.В. Основні тенденції розвитку світового продовольчого ринку та виробництво продовольства в Україні // Економіка АПК. 2018. № 9. С. 34 - 45. doi: 10.32317/22211055.201809034

4. Пугачов М.І. Розвиток зовнішньої торгівлі агропродовольчими товарами // Економіка АПК. 2019. № 3. С. 6 - 13. doi: 10.32317/2221-1055.201903006

5. Сичевський М.П. Глобальна продовольча безпека та місце України в їі досягненні // Економіка АПК. 2019. № 1. С. 6 - 17. doi: 10.32317/2221-1055.201901006

6. Приватизація спиртової галуззі [Електронний ресурс]. URL: privatisation. gov. ua. / alcohol - industry (дата звернення 10.01.2021).

7. Формування глобального і регіонального ринків сільськогосподарської сировини та продовольства : монографія // Ю.О. Лупенко та ін., за ред. Ю.О. Лупенка, М.І. Пугочова. Київ : ННЦ-ІАЕ, 2015. 320 с.

8. Штакал М.А., Пугачов В.М. Імпорт та перспективи імпортозаміщення в Україні // Економіка АПК. 2019. № 4. C. 80 - 88. doi: 10.32317/2221-1055.201904080

9. Le positionnement des filieres de l'aqriculture et de la peche a l’international [Електронний pecypc]. URL: https://www.franceagrimer.fr/fam/content/download/56474/document/20180301-Pr\%C3\%A9sentation\%20SIA\%20\%20international-7\%281\%29.pdf?version=3 (дата звернення 10.01.2021).

10. Commerce agro alimentaire de L'UE : Une croissance soutenue malgre les defies du coronavirus et du Brexit : website. URL: https://www.agro-media.fr/analyse/commerce-agroalimentaire-de-lue-une-croissance-soutenuemalgre-les-defis-du-coronavirus-et-du-brexit-44683.html (дата звернення 10.01.2021).

11. Le commerce et la cooperation economique entre L'Ukraine et la France : website. URL: https://france.mfa.gov.ua/fr/partenariat/289-torgovelyno-jekonomichne-spivrobitnictvo-mizh-ukrajinoju-ta-francijeju (дата звернення 10.01.2021).

12. Ukraine - Les importations de vins en hausse au premier semestre 2020 : website. URL: https://www.businessfrance.fr/ukraine-les-importations-de-vins-en-hausse-au-premier-semestre-2020 (дата звернення 10.01.2021).

Стаття надійшла 2.02.2021

Стаття прийнята до друку 16.02.2021

Доступно в мережі Internet 18.04.2021

Antonyuk P.

Ph.D., Researcher

Department of Market Mechanisms and Structures Institute of Market Problems and Economic \& Ecological Research of National Academy of Sciences of Ukraine Frantsuzskiy boulevard, 29, Odesa, Ukraine, 65044 E-mail: paul_antonyuk@ukr.net ORCID ID: 0000-0002-8100-2563

\section{Stupnytska T.}

Ph.D., Associate Professor Department of Accounting and Auditing E-mail: t.stupnitska@gmail.com ORCID ID: 0000-0002-2517-2795
Antonyuk 0.

Ph.D., Associate Professor

Department of Accounting and Auditing

E-mail: olegantoni@ukr.net ORCID ID: 0000-0002-9182-4982

\author{
Baraniuk Kh. \\ Assistant \\ Department of Accounting and Auditing \\ Odesa National Academy of Food Technologies \\ Kanatna str., 112, Odesa, Ukraine, 65039 \\ E-mail: baranyuk.kristina@gmail.com \\ ORCID ID: 0000-0002-3346-0332
}

\section{STATISTICAL ASSESSMENT OF FORMATION OF FOREIGN TRADE OF UKRAINE IN FINISHED FOOD PRODUCTS}

The article examines the issues of the current state of foreign trade in finished food products. It has been established that in the context of a significant increase in the export of agro-food products, the share of finished food products, that is, products with high added value, is gradually decreasing in its composition. The completeness of the study is based on the use of methods and techniques of the economic analysis.

The paper proposes in all aspects of the study to use the division of finished food products into two 
parts depending on their final purpose: human food products (commodity groups 16 - 22) and products that are not such (commodity groups 23 - 24). This approach makes it possible to establish that the export of finished food products is growing only due to a significant increase in sales of products that are not used in human nutrition - residues and waste from the food industry, tobacco and industrial tobacco substitutes. In recent years, it has been the main component in the export of finished food products. Imports of finished food products, which are growing much faster than exports, food products dominate, which may indicate insufficient food production and emerging problems of supplying the domestic market.

Studies of the geography of finished food products flows show significant changes - the CIS countries have given way of the largest importer to the countries of the European Union and Asia. In the course of the analysis, the features of export-import operations in individual regions of the world were established, taking into account changes in the commodity structure.

An assessment of the effectiveness of foreign trade in finished food products has been given. It has been concluded that the result of export-import transactions with human food products is a negative balance, which is covered by a significant positive balance in trade in goods of commodity group 23.

The study shows that the formation of a negative balance in food products trade takes place due to differences in the quality and nomenclature of exported and imported products, as a result of which import prices significantly exceed export prices. In addition, the growth of imports of a number of goods occurs in the context of a decrease in domestic production and related exports. The negative balance in recent years has reached such volumes that it is realistic to speak only of a decrease in this amount.

On the basis of the research carried out, recommendations have been presented for increasing exports and reducing imports for goods of some commodity groups.

Key words: agri-food products, finished food products, human food products, export, import, balance, commodity structure, geographic structure, statistical assessment.

\section{References}

1. Antonyuk, P., Antonyuk, O., Stupnytska, T., \& Holovachenko, L. (2019). Condition and results of trading of the agri-food products between Ukraine and the European union. Food Industry Economics, 11(1), 27-36; doi: 10.15673/fie.v11i1.1292

2. Derzhavna sluzhba statystyky Ukrainy. (2021). Retrieved January 10, 2021, from http://ukrstat.gov.ua/

3. Kyrylenko, I. H., Ivchenko, V. Ye., \& Demenchuk, V. V. (2018). Osnovni tendentsii rozvytku svitovoho prodovolchoho rynku ta vyrobnytstvo prodovolstva v Ukraini. Ekonomika APK. № 9, 34 - 45. doi: 10.32317/22211055.201809034

4. Puhachov, M. I. (2019). Rozvytok zovnishnoi torhivli ahroprodovolchymy tovaramy. Ekonomika APK. № 3, 6-13. doi: 10.32317/2221-1055.201903006

5. Sychevskyi, M. P. (2019). Hlobalna prodovolcha bezpeka ta mistse Ukrainy v yii dosiahnenni. Ekonomika APK. № 1, 6 - 17. doi: 10.32317/2221-1055.201901006

6. Pryvatyzatsiia spyrtovoi haluzzi. Retrieved January 10, 2021, from privatisation. gov. ua. / alcohol - industry

7. Lupenko, Yu. O. (2015). Formuvannia hlobalnoho i rehionalnoho rynkiv silskohospodarskoi syrovyny ta prodovolstva (Yu. O. Lupenko \& M. I. Puhochov, Eds.). Kyiv: NNTs-IAE.

8. Shtakal, M. A., \& Puhachov, V. M. (2019). Import ta perspektyvy importozamishchennia v Ukraini. Ekonomika APK. № 4, 80 - 88. doi: 10.32317/2221-1055.201904080

9. Le positionnement des filieres de l'aqriculture et de la peche a l'international. Retrieved January 10, 2021, from https://www.franceagrimer.fr/fam/content/download/56474/document/20180301-

Pr\%C3\%A9sentation\%20SIA\%20-\%20international-7\%281\%29.pdf?version=3

10. Commerce agro alimentaire de L'UE : Une croissance soutenue malgre les defies du coronavirus et du Brexit. Retrieved January 10, 2021, from https://www.agro-media.fr/analyse/commerce-agroalimentaire-de-lue-unecroissance-soutenue-malgre-les-defis-du-coronavirus-et-du-brexit-44683.html

11. Le commerce et la cooperation economique entre L'Ukraine et la France. Retrieved January 10, 2021, from https://france.mfa.gov.ua/fr/partenariat/289-torgovelyno-jekonomichne-spivrobitnictvo-mizh-ukrajinoju-tafrancijeju

12. Ukraine - Les importations de vins en hausse au premier semestre 2020. Retrieved January 10, 2021, from https://www.businessfrance.fr/ukraine-les-importations-de-vins-en-hausse-au-premier-semestre-2020

Received 2 February 2021

Approved 16 February 2021

Цитування згідно ДСТУ 8302:2015

Available in Internet 18.04.2021

Антонюк П.О., Антонюк О.П., Ступницька Т.М., Баранюк Х.О. Статистична оцінка формування зовнішньої торгівлі України готовими харчовими продуктами // Економіка харчової промисловості. 2021. Т.13, вип. 1. С. 3-11.

Cite as APA style citation

Antonyuk, P., Antonyuk, O., Stupnytska, T. \& Baraniuk, Kh. (2021). Statistical assessment of formation of foreign trade of Ukraine in finished food products. Food Industry Economics, 13(21), 3-11. 